\title{
ПОДРОСТКОВЫЕ ПОСТГОМИЦИДНЫЕ САМОУБИЙСТВА
}

\author{
А.В. Голенков \\ ФГБОУ ВО “Чувашский государственный университет имени И.Н. УАьянова», г. Чебоксары, Россия
} ADOLESCENT POST-HOMICIDE SUICIDES

Информация об авторе:

Голенков Андрей Васицьевич - доктор медицинских наук, профессор (SPIN-код: 7936-1466; Researcher ID: C-4806-2019; ORCID iD: 0000-0002-3799-0736; Scopus Author ID: 36096702300). Место работы и должность: заведующий кафедрой психиатрии, медицинской психологии и неврологии ФГБОУ ВО “Чувашский государственный университет им. И.Н. УАьянова". Адрес: Россия, г. Чебоксары, ул. Пирогова, 6. Телефон: +7 (905) 197-35-25, эмектронный адрес: golenkovav@inbox.ru

Information about the author:

Golenkov Andrei Vasilievich - MD, PhD, Professor (SPIN-code: 7936-1466; Researcher ID: C-4806-2019; ORCID iD: 0000-0002-3799-0736; Scopus Author ID: 36096702300). Place of work and position: Head of the Department of Psychiatrics, Medical Psychology and Neurology, I.N. Ulyanov Chuvash State University. Address: Russia, Cheboksary, 6 Pirogov Str. Tel.: +7 (905) 197-35-25, email: golenkovav@inbox.ru

Подростковые постгомицидные самоубийства (ПГСУ) встречаются исключительно редко. Однако в последние два десятилетия их стало существенно больше. Цель исследования: изучить подростковые ПГСУ в Российской Федерации. Материалы и методы. В анализ включено 12 подростков (молодых людей), со-

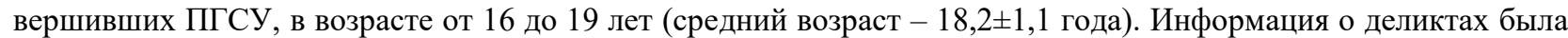
собрана в электронных средствах массовой информации, на сайтах Следственного комитета 11 субъектов Российской Федерации в период с 01 января 2009 г. по 31 декабря 2019 г. Анализировались также сведения о 39 жертвах ПГСУ (23 лиц мужского пола и 16 женского пола) в возрасте от 4 до 69 лет (средний возраст $27,3 \pm 17,5$ года), их социально-демографические, психопатологические и криминологические показатели. Результаты. Юноши совершили 11 ПГСУ, девушки - одно (в городской местности - семь, в сельской - пять). Чаще всего $(n=8)$ встречались внесемейные ПГСУ, реже партнёрские $(n=3)$ и семейные $(n=1)$. B 50,0\% случаев использовалось огнестрельное оружие, в 33,4\% - холодное, в 16,6\% - прочее (удушение, несколько способов). Способы убийств и самоубийств совпадали в 75,0\% случаев, самоубийства совершались в том же месте в $83,3 \%$, что и убийство через короткое время. 43,6\% жертв было в возрасте 13-19 лет и столько же - в 20-64. В трёх ПГСУ погибло 30 человек (массовое убийство учащихся и сотрудников в колледже г. Керчи; расстрел сослуживцев в военной части, расположенной в Костромской области и убийство топором членов трёх поколений одной семьи в Ульяновской области). Причинами ПГСУ являлись: длительные конфликты (буллинг, неуставные отношения в армии), расставание с партнершей (подругой), «чтобы родные не переживали после самоубийства». Психические расстройства подтвердились в одном случае, как и алкогольное опьянение (от психоактивных веществ) в момент ПГСУ. Суицидальные тенденции до убийства выявлялись в 33,3\%, к преднамеренным можно отнести 75\% совершённых убийств. Подростковые ПГСУ отличаются особо высокой долей жертв из числа сверстников и лиц трудоспособного возраста, убийства малолетних детей встречаются довольно редко; преобладают внесемейные ПГСУ. Агрессоры, как правило, младше жертв. Заключение. В силу раритета подростковые ПГСУ в России пока должным образом не изучены, профилактика практически не разработана, во многом совпадает с мерами предупреждения убийств и совершения самоубийств среди молодежи. Число жертв ПГСУ можно сократить ограничением доступа подростков к огнестрельному оружию, контролем за его использованием.

Ключевые слова: постгомицидные самоубийства, подростки (тинэйджеры), массовые убийства, Россия, интернет медиа репортажи

Постгомицидные самоубийства (ПГСУ) редкое криминальное деяние, которое встречается практически во всех странах мира $[1,2]$. Распространённость ПГСУ колеблется от 0,4 до 8,9 случаев на 1 млн жителей [3]; выявляется прямая связь как с убийствами, так и самоубийствами $[4,5]$. Подавляющее большинство
Posthomicide suicides (PHSU) is a rare criminal act that occurs in almost all countries of the world $[1,2]$. The prevalence of PHSU varies from 0.4 to 8.9 cases per 1 million inhabitants [3]; a direct relationship is revealed with both murders and suicides [4, 5]. The overwhelming majority $(90 \%$ or 
(90\% и более) преступников находится в возрасте 25 лет и старше, а среди подростков ПГСУ практически не встречается $[2,3,6]$. Чаще всего это лица мужского пола, убивающие женщин и детей с помощью огнестрельного оружия, младших себя по возрасту, а потом и себя [7-10]. Среди мотивов преобладают семейные (супружеские) конфликты, ревность, а также соматоневрологическая патология и психические расстройства $[1-3,9,11]$.

В России на сегодняшний день проведены единичные исследования ПГСУ, в которых анализировались их распространённость [12], социально - демографические, психологические и криминологические аспекты [13]. Доказана схожесть ПГСУ в России с другими странами мира, включая типологическую структуру $[14,15]$. При этом, если ПГСУ изучены среди взрослого населения $[2,3,6]$, включая людей пожилого и старческого возраста [16], то ПГСУ среди подростков (молодых людей) не изучались, за исключением одного недавно проведённого исследования в США [17]. В нём 47 случаев ПГСУ, совершённых лицами младше 21 года были взяты из регистрационной национальной системы насильственных смертей. Это анализ позволил получить лишь предварительные данные, нуждающиеся в более детальной проработке. В России, как, впрочем, и других странах мира, подростковые ПГСУ не изучались.

Настоящее исследование преследовало цель проанализировать особенности ПГСУ, совершённых подростками (молодыми людьми) в регионах Российской Федерации (РФ) за последние 11 лет.

Материалы и методы.

В исследование включено 12 подростков (молодых людей) в возрасте от 16 до 19 лет (средний возраст $18,2 \pm 1,1$ года). ПГСУ были совершены лицами не старше 19 лет в 11 (два случая зарегистрированы в г. Москва) регионах России в период с 01 января 2009 г. по 31 декабря 2019 г. Информация собиралась в электронных средствах массовой информации, на сайтах следственного комитета субъектов Российской Федерации и в ряде случаев в Википедии (общедоступной многоязычной универсальной интернет-энциклопедии $[18,19])$. Анализировалась также информация о 39 жертвах ПГСУ (23 лиц мужского пола и 16 женского пола) в возрасте от 4 до 69 лет (средний возраст $27,3 \pm 17,5$ года). На каждый случай ПГСУ выписывались социально-демографические, психопатологические и криминологические показатели (год и месяц преступления, регион России, пол, возраст убийцы / самоубийцы и его жертв; особенности деликта: совершенное в алкогольном опьянении, место совершения, способ убийства и самоубийства, число жертв, наличие психических расстройств у преступника и его жертв, вероятные причины деликта). more) of criminals are 25 years old or older, and practically is never committed by adolescents $[2,3,6]$. Most often these are males who kill women and youngsters with the help of firearms and then kill themselves [7-10]. Among the motives, family (marital) conflicts, jealousy, as well as somatoneurological pathology and mental disorders predominate $[1-3,9,11]$.

In Russia, to date, isolated studies of PHSU have been carried out, which analyzed their prevalence [12], socio-demographic, psychological and criminological aspects [13]. There is evidence that confirms the similarity of PHSU in Russia with PHSU in other countries of the world, including their typological structure $[14,15]$. PHSU committed by the adult population were studied $[2,3,6]$, including elderly people [16], however, PHSU committed by adolescents (younger people) were not studied, with the exception of one recently study conducted in the USA [17]. In it, 47 cases of PHSU committed by persons under the age of 21 were taken from the national registration system of violent deaths. This analysis allowed us to obtain only preliminary data that need more detailed study. In Russia, as well as in other countries of the world, teenage PHSU have not been studied.

This study was aimed at analyzing the characteristics of PHSU committed by adolescents (young people) in the regions of the Russian Federation (RF) over the past 11 years.

Materials and methods.

The study included 12 adolescents (young people) aged 16 to 19 (mean age 18.2 \pm 1.1 ). PHSU were committed by persons no older than 19 years of age in 11 regions of Russia (two cases registered in Moscow) during the period from January 1, 2009 to December 31, 2019. Information was collected in electronic media, on the websites of the investigation committee of the subjects of the Russian Federation and, in some cases, on Wikipedia (open-access multilingual universal Internet encyclopedia [18, 19]). Information was also analyzed on 39 victims of PHSU (23 males and 16 females) aged 4 to 69 (mean age - 27.3 \pm 17.5 ). Socio-demographic, psychopathological and criminological indicators were written out for each case of PHSU, among them the year and month of the crime, the region of Russia, gender, age of the murderer / suicide attempter and their victims; specifics of the crime: if it was committed under alcohol intoxication, the place of commission, method of the murder and suicide, the number of victims, the presence of mental disorders in the offender and their victims, the probable causes of the criminal act. 
Структура ПГСУ / The typological structure of the PHSU

\begin{tabular}{|c|c|c|c|c|c|c|c|}
\hline \multirow{3}{*}{$\begin{array}{l}\text { Вид ПГСУ } \\
\text { Kind of PHSU }\end{array}$} & \multirow{2}{*}{\multicolumn{2}{|c|}{$\begin{array}{l}\text { Всего } \\
\text { Total }\end{array}$}} & \multicolumn{4}{|c|}{ Пол жертв / Sex of victims } & \multirow{3}{*}{$\begin{array}{l}\text { Много жертв } \\
\text { Multi victims }\end{array}$} \\
\hline & & & \multicolumn{2}{|c|}{ Мужской / Male } & \multicolumn{2}{|c|}{ Женский / Female } & \\
\hline & $\mathrm{n}$ & $\%$ & $\mathrm{n}$ & $\%$ & $\mathrm{n}$ & $\%$ & \\
\hline Внесемейные / Extra-family & 8 & 66,7 & 20 & 87,0 & 11 & 68,8 & 2 \\
\hline Партнерские / Intimate & 3 & 25,0 & 1 & 4,3 & 2 & 12,5 & - \\
\hline Семейные / Familial & 1 & 8,3 & 2 & 8,7 & 3 & 18,7 & 1 \\
\hline Всего / Total: & 12 & 100,0 & 23 & 100,0 & 16 & 100,0 & 3 \\
\hline
\end{tabular}

Математико-статистическая обработка осуществлялась с помощью описательной статистики (М - среднее значение, $\sigma$ - стандартное отклонение).

Результаты исследования.

Юноши совершили ПГСУ в 11 случаях $(91,7 \%)$, девушка - в одном $(8,3 \%)$. Как видно из табл. 1 , чаще всего встречались внесемейные ПГСУ, далее партнёрские (девушка убила своего сожителя в его квартире; в двух случаях юноши убили своих подруг, с которыми вынуждены были расстаться по их инициативе) и один случай семейного ПГСУ (подросток зарубил топором мать, бабушку и дедушку, родных малолетних брата и сестру близнецов). Много жертв было в трёх случаях, лица мужского пола ими становились несколько чаще (59\%), чем женского (41\%).

Внесемейные ПГСУ были неоднородными деликтами. Так, в двух случаях убийства, совершённые лицами в возрасте 16 лет произошли спонтанно. Подростки взяли из дома охотничьи ружья и, играя с ними в ходе ссоры, а где-то случайно (по неосторожности), убили своих приятелей (друзей). Испугавшись уголовной ответственности за содеянное совершили самострел. В другом случае учащийся политехнического колледжа убил в классе ножом своего классного руководителя - учителя «Основ безопасности жизнедеятельности», с которым был в конфликте (тот обещал отчислить его за пропуски занятий и не сдачу зачёта). На фоне лежащего в крови преподавателя сделал селфи на смартфоне и выложил фото в сети. После этого, не выходя из класса, молодой человек совершил самоубийство с помощью этого же ножа. В четвёртом случае молодой человек привёл знакомую девушку на заброшенную ферму, в процессе сексуальных домогательств задушил её, а потом через некоторое время там же сам повесился.

Два случая внесемейных ПГСУ относятся к «расстрелу сослуживцев». В первом инциденте, 19-летний солдат застрелил разводящего караула 23-летнего ефрейтора и покинул часть с автоматом и боеприпасами; угнал машину, при преследовании не справился с её
Mathematical and statistical processing was carried out using descriptive statistics (M is the average value, $\sigma$ is the standard deviation).

The results of the study.

Young men completed PHSU in 11 cases (91.7\%), a girl did that only once (8.3\%). As can be seen from the table 1 , most common are extra-family PHSU, followed by the intimate PHSU (a girl killed the man she lived with in his apartment; in two cases, boys killed their girlfriends whom they had to leave on their initiative), family PHSU was registered only once (the teenager killed his mother, grandmother and grandfather, younger twin brother and sister with an ax). There were many victims in three cases; males became victims slightly more often $(59 \%)$ than females $(41 \%)$.

Extra-family PHSU were heterogeneous crimes. For example, in two cases of murder committed by persons aged 16 occurred spontaneously. The teenagers took hunting rifles from home and playing with them during a quarrel, and somewhere by chance (by negligence), killed their friends (acquaintances). Frightened of criminal liability for their actions, they killed themselves with the same firearms. In another case, a student at a polytechnic college killed a class teacher with a knife in the classroom - the teacher of the "Fundamentals of Life Safety" who he was in conflict with (the teacher promised to expel him for missing classes and not passing the test). Against the background of a teacher lying in the blood, the boy took a smartphone selfie and posted the photo on the web. After that, without leaving the class, the young man committed suicide with the same knife. In the fourth case, a young man brought a girl he knew to an abandoned farm, strangled her during sexual harassment, and then after a while he hanged himself there.

Two cases of extra-family PHSU are related to the "execution of colleagues". In the first incident, a 19-year-old soldier shot and killed a 23-year-old corporal who was on guard and left the unit with a machine gun and 
управлением, съехал в кювет, где и застрелился. Во втором случае, 18-летний солдат срочной службы, стоя на вахте, подошёл к караульной комнате и расстрелял из автомата, находящихся там пятерых военнослужащих. Трое погибли на месте (включая обидчика офицера части), один чуть позднее умер в больнице, другой был тяжело ранен. Выйдя из здания стрелял в других военнослужащих части; по счастливой случайности больше никто не пострадал. Расстреляв около 150 патронов, убил себя выстрелом в голову. Причинами обоих расстрелов сослуживцев явились неуставные отношения в частях с эпизодами психологического и физического насилия. В ходе расследования было установлено, что один из них рос без родителей, воспитывался бабушкой, за неделю до инцидента написал родным о «дедовщине» в части. Второй «завалил психодиагностический тест», поэтому в «учебке» его не допускали до караулов, не доверяли оружие. Окружающие характеризовали его как неуравновешенного, замкнутого, злопамятного, из-за этого к нему плохо относились другие сослуживцы; накануне был избит командиром роты. По мнению родственников других солдат, в части «царил бардак и неуставные отношения».

Ещё два случая ПГСУ можно отнести к так называемым «массовым расстрелам», шокирующим не только Россию, но и мировое сообщество. Одно, совершённое «керченским стрелком», подробно освещалось в средствах массовой информации, включая Википедию [19]. 17 октября 2018 г. в результате взрыва и стрельбы погиб 21 человек из числа учащихся и персонала учебного заведения, включая предполагаемого нападавшего. Пострадали 67 человек, 50 из них были госпитализированы. Считается, крупнейшим по количеству жертв ПГСУ (массовое убийство) в учебном заведении в новейшей истории Европы (России).

По версии следствия, В. Росляков планировал ПГСУ с января 2017 г. и действовал в одиночку. Для этого он легально приобрёл пятизарядное помповое ружьё Hatsan Escort, получив разрешение на него в правоохранительных органах, прошёл обучения правилам обращения с оружием, а также оказанию первой медицинской помощи. За несколько дней до преступления приобрёл в оружейном магазине 150 патронов с картечью.

Причиной стрельбы, по мнению экспертов, «послужил психологический кризис, возникший у молодого человека вследствие издевательств и унижений окружающих». Действия крымского убийцы по многим деталям повторяют план его «кумиров» из американской школы «Колумбайн» (время преступления, одежда, помповое ружье, взрывные устройства и зажигательная смесь, число погибших, способ и место само- ammunition, stole a car, couldn't not cope its driving during the pursuit, drove into a ditch, where he shot himself. In the second case, an 18 -year-old military conscript standing on guard, went to the guard room and shot five soldiers who were there from a machine gun. Three died on the spot (including the offender, the unit officer), one died a little later in the hospital, the other was seriously injured. Leaving the building, he shot at other military personnel, but fortunately no one else was hurt. Having shot about 150 rounds of ammunition, he killed himself with a shot in the head. The reasons for both executions of fellow employees were hazing in military units with episodes of psychological and physical violence. During the investigation it was established that one of them grew up without parents, was brought up by his grandmother, a week before the incident he wrote to his family about hazing in the unit. The second one "failed the psycho-diagnostic test", therefore, he was not allowed to be on guard in the "training", was not trusted the weapon. Others described him as unbalanced, withdrawn, vindictive, because of this, other colleagues treated him badly; the day before he was beaten by the company commander. According to the relatives of other soldiers, in the military unit "there was mess and hazing."

Two more cases of PHSU can be attributed to the so-called "mass executions", shocking not only to Russia but also to the international community. One, committed by the "Kerch shooter," was covered in detail in the media, including Wikipedia [19]. On October 17, 2018, 21 people from the number of students and staff of the educational institution, including the alleged attacker, died as a result of the explosion and shooting. 67 people were injured, 50 of them were hospitalized. It is believed to be the largest PHSU in terms of the number of victims (mass murder) in an educational institution in the recent history of Europe (Russia).

According to the investigation, $\mathrm{V}$. Roslyakov planned the PHSU since January 2017 and acted alone. To do this, he legally acquired the Hatsan Escort five-shot pumpaction shotgun, obtained permission in law enforcement agencies, and received training on the rules for handling weapons and providing first aid. A few days before the crime, he acquired 150 rounds of ammunition with buckshot in an armament store.

The reason for the shooting, according to experts, "was a psychological crisis that arose in a young man as a result of bullying and humiliation of others." The Crimean killer's actions in many details repeat the plan of his "idols" from the American Columbine school (time of crime, clothes, pump-action shotgun, explosive devices and incendiary mixture, number of the dead, method and place of sui- 
убийства) $)^{1}$. Он обсуждал со знакомыми в сети массовый расстрел («круто было бы устроить бойню»), способы самоубийства (цианистый калий и огнестрел). Известно, что три года ходил в колледж со штыкножом, все об этом знали. После совершения преступления направился в библиотеку колледжа, где совершил самоубийство, выстрелив себе в голову из ружья [19].

Второе ПГСУ, произошло 14 ноября 2019 г. в Амурском колледже строительства и жилищнокоммунального хозяйства. 19-летний студент пронёс в учебное заведение зарегистрированное на своё имя многозарядное помповое ружьё и открыл огонь по ученикам в аудитории. Один студент погиб на месте, ещё трое (по другим данным пятеро) получили ранения разной степени тяжести. Прибывшая на место полиция заблокировала стрелка в одном из кабинетов, где он застрелился. У студента, устроившего стрельбу в колледже Благовещенска, были суицидальные наклонности. Их выявили сотрудники призывной комиссии, но не сообщили в учебное заведение. Сокурсниками характеризовался как крайне замкнутый, не имеющий друзей, над ним якобы издевались одногруппники, подвергался остракизму со стороны других студентов колледжа. Начал стрелять после того, как его за опоздание удалили из аудитории.

Касаясь психических расстройств у подростков, совершивших описанные ПГСУ, информация о них крайне скудная, однако и в ней в семи случаях из 12 прослеживаются закономерности, описанные в литературе $[11,17]$. Речь идёт о наличии депрессивных и стрессовых состояний у трёх нападавших $(25,0 \%)$, явные суицидальные тенденции у четырёх $(33,3 \%)$. Отдельные их признаки обнаруживаются в предсмертных записках, в переписке со сверстниками в социальных сетях (о выборе способа самоубийства), документации призывной комиссии и консультациях (обследовании) у специалистов. К преднамеренным можно отнести $75 \%$ совершённых подростками убийств.

В подростковых ПГСУ редко жертвами становятся родные и близкие люди, чаще всего это знакомые люди из места учёбы, службы, группы сверстников (сослуживцы, друзья, подруги, студенты одного колледжа, преподаватели).

В табл. 2 представлены виды ПГСУ с учётом числа жертв. Видно, что с двумя и более жертвами было $25 \%$ ПГСУ (максимальное число жертв - 21), с одной $75 \%$. Выявлена чёткая связь между числом жертв и использованием огнестрельного оружия (автомата Калашникова, многозарядных помповых ружей). cide). He discussed mass shooting with the acquaintances on the web ("it would be cool to arrange a massacre"), methods of suicide (potassium cyanide and firearms). It is known that for three years he went to college with a bayonet-knife, which everyone knew about. After committing a crime, he went to the college library, where he committed suicide by shooting himself in the head with a gun [19].

The second PHSU took place on November 14, 2019 at the Amur College of Construction and Housing and Communal Services. A 19-year-old student carried a multi-shot pump-action shotgun registered in his name into the school and opened fire on students in the audience. One student died on the spot, three more (according to other sources, there were five) were injured with varying severity. Arriving at the place, the police blocked the shooter in one of the offices where he shot himself. The student who shot at the college of Blagoveshchensk had suicidal tendencies. They were identified by members of the draft commission, but were not reported to the educational institution. Fellow students described him as extremely reserved, having no friends, allegedly he was mocked by the classmates and was ostracized by other college students. He started shooting after he was removed from the audience for being late.

Concerning mental disorders in adolescents who have completed the described PHSU, the information about the presence of such is extremely scarce, however, in seven of 12 cases, the patterns described in the literature are also traced $[11,17]$. It concerns the presence of depressive and stressful conditions for three attackers $(25.0 \%)$, clear suicidal tendencies for four $(33.3 \%)$. Some of their signs are found in suicide notes, in correspondence with peers on social media (about choosing the method of suicide), documentation of the draft board and consultations (examination) with specialists. $75 \%$ of murders committed by adolescents can be attributed to deliberate acts.

Relatives or close ones are rare victims in teenage PHSU, most often the victims are people the offenders know from a place of study or military service, peer groups (colleagues, fellow soldiers, friends, girlfriends, college students, teachers).

The table 2 presents the types of PHSU with the number of victims. It can be seen that there were $25 \%$ PHSU with two or more victims (maximum number of victims - 21), and $75 \%$ with one victim. A clear connection was found between the number of victims and the use of firearms (AK-47, multi-shot pumpaction shotguns).

\footnotetext{
${ }^{1}$ Массовое убийство в школе «Колумбайн» // wikipedia.org. [Электронный ресурс]. Режим доступа: https://ru.wikipedia.org/wiki/ (дата обращения: 17.05.2020) / Massacre at Columbine School // wikipedia.org. [Electronic resource]. Access mode: https://ru.wikipedia.org/wiki/ (accessed: 05.17.2020).
} 
Орудия / способы убийств и самоубийств ПГСУ и число жертв

Weapons / methods of homicides and suicides and number of murder victims

\begin{tabular}{|c|c|c|c|c|c|c|}
\hline \multirow[t]{2}{*}{$\begin{array}{l}\text { Орудия / способы } \\
\text { Weapons / methods }\end{array}$} & \multicolumn{2}{|c|}{$\begin{array}{l}\text { Убийства } \\
\text { Homicides } \\
(\mathrm{n}=12)\end{array}$} & \multicolumn{2}{|c|}{$\begin{array}{c}\text { Число жертв убийств } \\
\text { The number of homicide } \\
\text { victims }(\mathrm{n}=39)\end{array}$} & \multicolumn{2}{|c|}{$\begin{array}{l}\text { Самоубийства } \\
\text { Suicides } \\
(\mathrm{n}=12)\end{array}$} \\
\hline & $\mathrm{n}$ & $\%$ & $\mathrm{n}$ & $\%$ & $\mathrm{n}$ & $\%$ \\
\hline $\begin{array}{l}\text { Огнестрельное } \\
\text { Firearm }\end{array}$ & 6 & 50,0 & 29 & 74,4 & 6 & 50,0 \\
\hline $\begin{array}{l}\text { Холодное } \\
\text { Steel arms }\end{array}$ & 4 & 33,4 & 7 & 17,9 & 2 & 16,7 \\
\hline $\begin{array}{l}\text { Удушение / Повешение } \\
\text { Strangulation / Suffocation }\end{array}$ & 1 & 8,3 & 2 & 5,1 & 3 & 25,0 \\
\hline $\begin{array}{l}\text { Падение с высоты } \\
\text { Falling from a height }\end{array}$ & - & - & - & - & 1 & 8,3 \\
\hline $\begin{array}{l}\text { Несколько } \\
\text { Several methods }\end{array}$ & 1 & 8,3 & 1 & 2,6 & - & - \\
\hline $\begin{array}{l}\text { Всего } \\
\text { Total: }\end{array}$ & 12 & 100,0 & 30 & 100,0 & 12 & 100,5 \\
\hline
\end{tabular}

Как видно из табл. 2, самым частым способом убийства и самоубийства было использование огнестрельного оружия (в подавляющем числе случаев ружья), довольно часто преступники прибегали к колюще-режущим предметам (ножам) и удушению. Из способов самоубийств, кроме огнестрельного оружия, использовалось повешение, холодное оружие и падение с высоты. Несколько орудий / способов встречалось в одном случае.

В большинстве случаев самоубийства совершались в том же самом месте, что и убийство, обычно в помещениях (колледжей, квартиры, заброшенных хозяйственных постройках - ферма, маслоцех). Значительно реже это были - территория воинской части, лесные массивы. В двух случаях она менялась, например, убийство совершено в воинской части, а самоубийство - в лесном массиве невдалеке от неё, убийство - в соседской квартире, а самоубийство - на балконе своей квартиры.

Способы убийств и самоубийств совпадали в 75,0\% случаев, чаще всего с использованием огнестрельного (50\%) оружия, реже с помощью колющих / режущих предметов $(16,7-33,4 \%)$ и удушения $(8,3-25,0 \%)$. Алкогольное опьянение у убийц указывалось лишь в одном случае $(8,3 \%)$.

Чаще причинами ПГСУ были различные конфликты, ссоры $(\mathrm{n}=8)$, разрыв партнерских отношений, ревность $(\mathrm{n}=3)$, «чтобы родные не переживали из-за самоубийства» $(\mathrm{n}=1)$.

В табл. 3 представлены половозрастные группы жертв ПГСУ. Видно, что преобладали лица подросткового и трудоспособного возраста. Убийцы значительно уступали по возрасту своим жертвам $(18,2 \pm 1,1$ года и $27,3 \pm 17,5$ года соответственно).
As can be seen from the table 2 , the most common method of killing and suicide was the use of firearms (in the vast majority of cases, guns), quite often criminals resorted to steel arms (knives) and asphyxiation. Besides firearms as a methods of suicide, there were also hanging, steel arms and falling from a height. Several tools / methods were encountered in one case.

In most cases, suicides occurred in the same place as the murder, usually on the premises (colleges, apartments, abandoned outbuildings - a farm, an oil workshop). Much less often it was the territory of the military unit, forests. In two cases, the place changed, for example, a murder was committed in a military unit while the follow-up suicide occurred in a nearby forest, or a murder was committed in a neighboring apartment, while the suicide followed on the balcony of the murder's apartment.

The methods of murder and suicide coincided in $75.0 \%$ of cases, most often with the use of firearms $(50 \%)$, less often with the help of piercing / cutting objects (16.7-33.4\%) and strangulation (8.3-25.0\%). Alcohol intoxication among killers was indicated in one case only $(8.3 \%)$.

Most often, the reasons for PHSU were various conflicts, quarrels $(n=8)$, partnership breakdowns, jealousy $(n=3)$, "so that relatives did not have to worry about suicide" $(n=1)$.

The table 3 shows the age and sex groups of victims of PHSU. It is seen that the victims are predominantly adolescents and people of working age. Killers were significantly younger in age compared to their victims (18.2 \pm 1.1 years of age and $27.3 \pm 17.5$ years of age, respectively). 
Половозрастные группы жертв ПГСУ / Sex and age groups of victims of PHSU

\begin{tabular}{l|c|c|c|c|c|c}
\hline \multirow{2}{*}{$\begin{array}{c}\text { Boзрастные группы } \\
\text { Age groups }\end{array}$} & \multicolumn{2}{c|}{$\begin{array}{c}\text { Оба пола / Both sexes } \\
(\mathrm{n}=39)\end{array}$} & \multicolumn{2}{c|}{$\begin{array}{c}\text { Пол мужской / Male } \\
(\mathrm{n}=23)\end{array}$} & \multicolumn{2}{c}{$\begin{array}{c}\text { Пол женский / Female } \\
(\mathrm{n}=16)\end{array}$} \\
\cline { 2 - 8 } & $\mathrm{n}$ & $\%$ & $\mathrm{n}$ & $\%$ & $\mathrm{n}$ & $\%$ \\
\hline 4 года & 2 & 5,1 & 1 & 4,35 & 1 & 6,25 \\
\hline $13-19$ & 17 & 43,6 & 9 & 39,1 & 8 & 50,0 \\
\hline $20-64$ & 17 & 43,6 & 12 & 52,2 & 5 & 31,25 \\
\hline$\geq 65$ & 3 & 7,7 & 1 & 4,35 & 2 & 12,5 \\
\hline \multirow{2}{*}{ Всего / Total: } & 39 & 100,0 & 23 & 100,0 & 16 & 100,0 \\
& & 100,0 & & 59,0 & & 41,0 \\
\hline
\end{tabular}

Обсуждение результатов .

Включение 19-летних в исследование обусловлено критериями фонда $\mathrm{OOH}$ в области народонаселения, который к подросткам относит лиц в возрасте 10-19 лет (ранним подростковым возрастом считается период 1014 лет, старшим - 15-19 лет). Кроме того, тинэйджер с английского языка буквально означает период от 13 до 19 лет (teen + age). Недавно проведённое в США исследование в группу подростков включило лиц в возрасте до 21 года [17], при этом есть предложение считать таковыми молодых людей вплоть до 24 лет [20].

По сравнению с данными литературы, согласно которым среди подростков лидируют партнерские ПГСУ [17], мы обнаружили внесемейные случаи, довольно вариабельными по своим мотивам и числу жертв. Сюда вошли расстрелы военнослужащих в армии, работников и учащихся колледжей, другие убийства, совершённые разными способами знакомых и незнакомых людей. При этом наши наблюдения о преобладании мужчин в качестве агрессоров с использованием огнестрельного оружия совпали с данными литературы [2, $7,8-10,12,13]$, но отличались бо̀льшей долей среди погибших лиц мужского пола, что отчасти объясняется местом совершения ПГСУ (армейские части), профилем учебных заведений и полом жертв-обидчиков.

В работе A. Adhia и соавт. [17] использовалась классификация Т. Joiner [21], основанная на извращении четырех добродетелей (справедливости, милосердии, славы, долга), а также таких категорий, как извращение самоконтроля и судьбы. Как видно из табл. 4 , имеется некоторая схожесть в распределении случаев ПГСУ. Извращение героической славы наблюдалось нами при ПГСУ, совершённых в учебных заведениях, хотя отчасти вместе с желанием прославиться присутствовали и мотивы ложной справедливости, с намерениями отомстить, наказать своих обидчиков. Наиболее четко такое выявлялось в «армейских расстрелах» [18]. Представляет интерес извращение такой добродетели, как милосердие. Среди собранных нами случаев 16летний подросток убил во время сна пятерых членов своей семьи, чтобы они не переживали по поводу его смерти после запланированного им самоубийства.
The discussion of the results.

The inclusion of 19-year-olds in the study is due to the criteria of the United Nations Population Fund, which refers to people aged 10-19 years old as adolescents (where the period of 10-14 years old is considered to be early adolescence, and the period pf15-19 is seen as later adolescence). In addition, the English word "a teenager" literally encompasses the period of 13 to 19 (teen + age). A recent United States study suggested to include people under the age of 21 in the adolescents group [17], and there is another proposal to consider young people under 24 years of age as such [20].

Compared to the literature, according to which intimate PHSU are leading among teenagers [17], we found extra-family cases to be more prevalent and quite variable in terms of their motives and the number of victims. This included executions of military personnel in the army, college workers and students, and other murders of friends and strangers committed in various ways. At the same time, our observations about the predominance of men as aggressors using firearms coincided with those in the literature $[2,7,8-10,12,13]$, but differed in that we found a larger share of males among the victims as well, which is partly explained by the location of the commission of PHSU (military units), the profile of educational institutions and the gender of the offending victims.

In their work, A. Adhia et al. [17] used the classification by $\mathrm{T}$. Joiner [21] that is based on a perversion of the four virtues (justice, mercy, glory, duty), as well as a perversion of such categories as self-control and fate. As can be seen from the table 4, there is some similarity in the distribution of PHSU cases. A perversion of heroic glory was observed by us at PHSU committed in educational institutions, although partly with the desire to become famous there were also motives of false justice, with the intentions of revenge and punishment of the offenders. This was most clearly revealed in the "army executions" [18]. Of interest is the perversion of such virtue as mercy. 
Сопоставление мотивов подростковых ПГСУ по Т. Joiner [21]

Comparison of the motives of adolescent PHSU according to T. Joiner [21]

\begin{tabular}{|c|c|c|c|c|}
\hline \multirow{2}{*}{$\begin{array}{l}\text { Извращения: } \\
\text { Perversion of: }\end{array}$} & \multicolumn{2}{|c|}{$\begin{array}{l}\text { По А. Adhia и coaвт., } 2020 \text { [17] } \\
\text { Data of [17] }\end{array}$} & \multicolumn{2}{|c|}{$\begin{array}{c}\text { Данные настоящего исследования } \\
\text { Data from this study }\end{array}$} \\
\hline & $\mathrm{n}$ & $\%$ & $\mathrm{n}$ & $\%$ \\
\hline Справедливости / Justice & 8 & 17,0 & 5 & 41,7 \\
\hline Милосердия / Mercy & 1 & 2,1 & 1 & 8,2 \\
\hline Героической славы / Heroic glory & - & - & 2 & 16,7 \\
\hline Долга / Duty & - & - & - & - \\
\hline Самоконтроля / Self-control & 11 & 23,4 & 2 & 16,7 \\
\hline Судьбы / Fate & - & - & - & - \\
\hline \multirow[t]{2}{*}{$\begin{array}{l}\text { Невозможно определить } \\
\text { Unable to categorize }\end{array}$} & 27 & 57,5 & 2 & 16,7 \\
\hline & 47 & 100,0 & 12 & 100,0 \\
\hline
\end{tabular}

Нам встретился ещё один похожий случай, когда 17-летний подросток «из жалости» 21 ударом ножа зарезал свою 70-летнюю бабушку-опекуншу («чтобы не расстраивалась после его смерти» вследствие самоубийства) и поехал в сторону моста совершать самоубийство прыжком с высоты, но был задержан сотрудниками правоохранительных органов.

Можно согласиться с А. Adhia и соавт. в том, что нередко трудно определить мотивы ПГСУ, самоубийство было первичным, доминирующей идеей, способствующей убийству [17]. В части случаев самоубийство изначально не планировалось, но в результате произошедшего убийства было совершено (чаще всего вследствие извращения самоконтроля, судьбы, а по данным отечественной литературы, из-за страха строгого уголовного наказания [20]). Эти вопросы являются чрезвычайно важными и требующими дополнительного сбора информации и тщательных исследований.

Среди случаев не встретились детские ПГСУ, хотя в федеральной выборке таковых было 16,4\% [14]. В одном нашем наблюдении 19-летняя женщина с грудным ребёнком убила соседа, являющегося отцом ребёнка, а потом себя. Что стало с ребёнком неизвестно, но такие вопросы задавались в сети. Анализ 43 случаев судебно-психиатрической экспертизы за 30 лет (19822011) показал, что среди убийц новорождённых детей была часть несовершеннолетних. Они совершили преступления из-за страха перед родителями, стыда и по другим причинам, в последующем у некоторых возникали суицидальные мысли и депрессивные состояния [22]. Поэтому ПГСУ вполне вероятны, так как у женщин во время беременности и послеродовом периоде весьма характерны суицидальные проявления [23]. Среди 17 матерей, убивших своих детей, семь пытались покончить жизнь самоубийством. Причём многие демонстрировали признаки суицидальных тенденций до
Among the cases we collected, a 16-yearold teenager killed five members of his family while at sleep so that they would not worry about his death after his planned suicide. There was another similar case when a 17year-old teenager stabbed 21 times his 70year-old guardian grandmother "out of pity" ("so that she were not upset after his death because of suicide) and on the way to the bridge with the aim to commit suicide by jumping from a height, he was detained by law enforcement officials.

One can agree with A. Adhia et al. on the fact that it is often difficult to determine the motives of the PHSU, suicide was the primary, dominant idea conducive to murder [17]. In some cases, suicide was not originally planned, but it was committed as a result of the killing that occurred (most often as a result of perversion of self-control, fate, and according to Russian research because of fear of severe criminal punishment [20]). These issues are extremely important and require additional collection of information and thorough research.

Among the cases there were no pediatric PHSU, even though in the federal sample there were $16.4 \%$ of those [14]. In one of our observations, a 19-year-old woman with an infant killed her neighbor who was the father of the child, and then killed herself. What happened to the child is unknown, but such questions were asked online. An analysis of 43 cases of forensic psychiatric examination over 30 years (1982-2011) showed that among the murderers of newborn children, there were some minors. They committed crimes because of fear of their parents, shame, and for other reasons, subsequently some had suicidal thoughts and depressive states [22]. Therefore, PHSU are quite likely, since suicidal manifestations are very characteristic of women dur- 
совершенного преступления, в основе которого в восьми случаях лежали так называемые «альтруистические» и «супружеские» мотивы убийства ребёнка [7, 9, $12]$.

В России стрельба в школе впервые случилась в феврале 2014 г. в г. Москва, когда 15-летний ученик застрелил на глазах одноклассников учителя географии, а потом сотрудника вневедомственной охраны и тяжело ранил патрульного. Очевидно, только присутствие отца на месте трагедии, позволило остановить дальнейшие убийства и запланированное самоубийство; на судебно-психиатрической экспертизе «подросток-стрелок» был признан невменяемым [24]. С тех пор произошёл ряд нападений на школы гг. Москвы, Перми, Улан-Уде, Московской области со значительным количеством пострадавших, но преступники остались живы, поэтому эти случаи не включены в настоящее исследование [25]. Но в целом прослеживается тенденция к росту таких преступлений как у нас в стране, так и в странах мира [26]. Так, в течение 20132015 гг. в США зарегистрировано 154 (35, 55 и 64) инцидента в школах с использованием огнестрельного оружия [26]. В США массовые убийства с применением огнестрельного оружия происходят примерно каждые две недели, а школьные в среднем - ежемесячно [27]. Кросс-национальное исследование в 171 стране мира показало, что «массовые убийства = расстрелы» следует с большой вероятностью ожидать в США и других странах с высоким уровнем владения населением огнестрельным оружием, даже, если граждане являются «относительно мирными» и «психически здоровыми» [28]. Число погибших всегда больше, если массовый убийца «запланировал» (совершил) самоубийство, особенно, когда деликт произошёл в Европе [29]. Они с меньшей вероятностью будут признаны невменяемыми (больными шизофренией) [30].

Огнестрельное оружие является самым частым способом ПГСУ как среди подростков, так и среди взрослого населения. Это не случайно. В период с 2005 по 2015 гг. уровень самоубийств, совершённых с помощью огнестрельного оружия среди подростков США удвоился, особенно в сельских поселениях. Предлагается сократить доступ к домашнему огнестрельному оружию независимо от его вида [31]. Огнестрельное оружие является и самым частым орудием убийств среди подростков, имеющих к нему доступ. Особенно часто убивают девушек, состоящих в интимных отношениях, по причине расставания, ревности, нежелательной беременности [32].

Наши исследования убийств и самоубийств, совершённых подростками в Чувашии показали крайне редкое использование огнестрельного оружия [33, 34], чего нельзя сказать про ПГСУ. Поэтому ограничение ing pregnancy and the postpartum period [23]. Among the 17 mothers who killed their children, seven tried to commit suicide. Moreover, many showed signs of suicidal tendencies before the crime, which in eight cases was based on the so-called "altruistic" and "marital" motives for killing a child [7, 9, 12].

In Russia, shooting at a school first occurred in February 2014 in Moscow, when a 15-year-old student shot a geography teacher in front of classmates, then a private security officer and severely wounded a patrol officer. Obviously, only the presence of his father at the scene of the tragedy allowed to stop further killings and planned suicide; at the forensic psychiatric examination, the "shooter teenager" was declared insane [24]. Since then, there have been a number of attacks on schools of the cities in Moscow, Perm, UlanUde, Moscow region with a significant number of victims, but the criminals remained alive, so these cases are not included in this study [25]. But on the whole, there is a tendency towards an increase in such crimes both in our country and in the countries of the world [26]. Thus, during 2013-2015 in the USA, $154(35,55$, and 64) incidents with the use of firearms were recorded in schools [26]. In the United States, firearms killings occur approximately every two weeks, and school killings, on average, every month [27]. A cross-national study in 171 countries around the world showed that "mass killings = executions" should be most likely to be expected in the United States and other countries with a high level of possession of firearms, even if citizens are "relatively peaceful" and "mentally healthy" [ 28]. The death toll is always greater if the mass killer "planned" (committed) suicide, especially when the criminal act occurred in Europe [29]. They are less likely to be recognized as insane (patients with schizophrenia) [30].

Firearms are the most common method of PHSU, both among adolescents and among adults. This is not an accident. Between 2005 and 2015 the rate of suicides committed with firearms among US teenagers has doubled, especially in rural areas. It is proposed to reduce access to firearms at homes regardless of their type [31]. Firearms are also the most common murder weapon among adolescents who have access to it. Especially often girls who are in an intimate relationship are killed, because of separation, jealousy, or unwanted pregnancy [32].

Our studies of murders and suicides committed by adolescents in Chuvashia showed an extremely rare use of firearms [33, 34], which cannot be said about PHSU. There- 
доступа к огнестрельному оружию может сократить число жертв в результате преступлений. Так, после проведения реформы об оружии в Австралии в 1996 году, за 10 лет не было зарегистрировано ни одного случая «массовых убийств», произошло снижение смертности от самоубийств и убийств с применением огнестрельного оружия [35].

Что касается случаев, связанных с «расстрелом сослуживцев», это особый вид деликта, отличающийся от обычных ПГСУ. В нашей стране с 2001 по 2010 гг. Произошло 26 таких преступлений, с самоубийством (5) агрессора около 20\% (ПГСУ), то есть почти каждое пятое преступление [18]. Если в России ведущими причинами являются неуставные отношения, то за рубежом проблемы со здоровьем, в том числе посттравматические стрессовые расстройства, возникшие в результате службы в армии [36]. ПГСУ, совершённые военнослужащими, отличаются от аналогичных инцидентов, произошедших с гражданскими лицами.

Ограничениями нашего исследования являются: малочисленность наблюдений подростковых ПГСУ, их значительная типологическая вариабельность, отсутствие многих социально-психологических характеристик агрессоров и жертв, состояния их психического здоровья, мотивации совершения как убийств, так и самоубийств.

Заключение.

Проведённый анализ позволил получить предварительные данные о ПГСУ молодых людей, которые имеют отличия от более старшей возрастной группы; преобладают внесемейные ПГСУ, многие из которых можно назвать корпоративными ${ }^{1}$. Среди жертв наблюдается большая доля людей молодого и трудоспособного возраста. Недооцениваются последствия буллинга (бойкота сверстниками, оскорблений, других форм издевательств и разнообразных проявлений дискриминации в молодежной среде), хронического стресса, депрессивных (психических) расстройств у подростков в совершении агрессивных действий, направленных на себя и окружающих. Для лучшего понимания этого феномена и разработки профилактических мер следует продолжить сбор случаев таких ПГСУ не только в интернет-изданиях, но и в реальной жизни (например, в судебно-психиатрической, судебно-медицинской и юридической практике) с участием специалистов субъектов Российской Федерации. Число ПГСУ и их жертв можно сократить ограничением доступа подростков к огнестрельному оружию и контролем за его использованием. fore, restricting access to firearms can reduce the number of victims of the crime. So, after the arms reform in Australia in 1996, not a single case of "mass killings" was recorded in 10 years, there was a decrease in mortality from suicides and murders using firearms [35].

As for the cases connected with the "execution of colleagues", it is a specific kind of crime that differs from the usual PHSU. In our country from 2001 to 201026 such crimes took place, about $20 \%$ ended with the suicide (5) of the aggressor (PHSU), that is, almost every fifth crime [18]. If in Russia the leading causes were hazing, abroad these were health problems, including post-traumatic stress disorders that have arisen as a result of military service [36]. PHSU committed by military personnel are different from similar incidents that occurred with civilians.

The limitations of our study are: the paucity of observations of adolescent PHSU, their significant typological variability, the absence of many socio-psychological characteristics of aggressors and victims, their mental health status, motivation for committing both murders and suicides.

Conclusion

The analysis made it possible to obtain preliminary data on the PHSU of young people since they differ from the PHSU committed by older age groups; extra-family PHSU prevail, many of which can be called corporate. Among the victims there is a large proportion of people of a young and working age. The consequences of bullying (boycotting by peers, insults, other forms of bullying and various manifestations of discrimination among young people), chronic stress, depressive (mental) disorders in adolescents in committing aggressive actions directed at themselves and others are underestimated. For better understanding of this phenomenon and the development of preventive measures, it is necessary to continue collecting cases of such PHSU not only in online publications, but also in real life (for example, in judicial psychiatric, forensic and legal practice) with the participation of specialists from the subjects Russian Federation. The number of PHSU and their victims can be reduced by restricting adolescents' access to firearms and monitoring their use.

\footnotetext{
${ }^{1}$ Корпорация: 1) замкнутая группа лиц, объединенная общностью интересов (сословных, профессиональных и др.); 2) объединение, союз, общество. Словарь иностранных слов: [более 4500 слов и выражений] / Н.Г. Комлев. М.: Эксмо, 2006. 669 с. / Corporation: 1) a closed group of individuals, united by a commonality of interests (social, professional, etc.); 2) association, union, community. Dictionary of foreign words: [more than 4,500 words and phrases] / N.G. Komlev. M .: Eksmo, 2006.669 s.
} 


\section{Литература / References:}

1. Large M., Smith G., Nielssen O. The epidemiology of homicide followed by suicide: a systematic and quantitative review. Suicide Life Threat. Behav. 2009. Jun.; 39 (3): 294-306. DOI:10.1521/suli.2009.39.3.294.

2. Liem M., Oberwittler D. Homicide Followed by Suicide in Europe. Handbook of European Homicide Research: Patterns, Explanations, P. and Country Studies. Springer Science+Business Media. 2012; 197-215. DOI: 10.1007/978-1-4614-0466-8_12

3. Голенков А.В. Постгомицидные самоубийства: обзор литературы. Суицидология. 2018; 9 (3): 3-15. doi https://doi.org /10.32878/suiciderus.18-09-03(32)-3-15. [Golenkov A.V. Post-homicide suicides: review of literature. Suicidology. 2018; 9 (3): 3-15. DOI: https:// doi.org/10.32878/suiciderus.18-09-03(32)-3-15.] (In Russ)

4. Liem M., Nieuwbeerta P. Homicide followed by suicide: a comparison with homicide and suicide. Suicide Life Threat Behav. 2010. Apr.; 40 (2): 133-145. DOI: 10.1521/suli.2010.40.2.133

5. McPhedran S., Eriksson L., Mazerolle P., De Leo D., Johnson H., Wortley R. Characteristics of Homicide-Suicide in Australia: A Comparison With Homicide-Only and Suicide-Only Cases. J. Interpers Violence. 2018. Jun.; 33 (11): 1805-1829. DOI $10.1177 / 0886260515619172$

6. Liem M., Barber C., Markwalder N., Killias M., Nieuwbeerta P. Homicide-suicide and other violent deaths: an international comparison. Forensic Sci. Int. 2011. Apr. 15; 207 (1-3): 70-76. DOI: $10.1080 / 14789940802364369$

7. Chan C.Y., Beh S.L., Broadburst R.G. Homicide-suicide in Hong Kong, 1989-1998. Forensic. Sci. Int. 2004. Mar. 10; 140 (2-3): 261-267. DOI: 10.1016/s0379-0738(03)00350-5

8. Dogan K.H., Demirci S., Gunaydin G., Buken B. Homicidesuicide in Konya, Turkey between 2000 and 2007. J. Forensic Sci 2010. Jan.; 55 (1): 110-115. DOI: $10.1111 / \mathrm{j} .1556-$ 4029.2009.01239.x

9. Stack S. Homicide followed by suicide: An analysis of Chicago data. Criminology. 1997. Aug.; 35 (3): 435-453.

10. De Koning E., Piette M.H. A retrospective study of murdersuicide at the Forensic Institute of Ghent University, Belgium: 1935-2010. Med. Sci. Law. 2014. Apr.; 54 (2): 88-98. DOI: $10.1177 / 0025802413518018$

11. Flynn S., Gask L., Appleby L., Shaw J. Homicide-suicide and the role of mental disorder: a national consecutive case series. Soc. Psychiatry Psychiatr. Epidemiol. 2016. Jun.; 51 (6): 877-884. DOI: $10.1007 / \mathrm{s} 00127-016-1209-4$

12. Голенков А.В. Распространенность и особенности постгомицидных суицидов на примере одного из регионов России. Психическое здоровье. 2018; 16 (2): 9-13. DOI 10.25557/2074-014X.2018.02.9-13. [Golenkov A.V. Prevalence and peculiarities of post-homicide suicides on the example of one of the regions of Russia. Mental health. 2018; 16 (2); 9-13.] (In Russ)

13. Голенков А.В. Постгомицидные самоубийства: описание 5 случаев. Российский психиатрический журнал. 2017; 2: 12 16. [Golenkov A.V. Post-homicide suicide: a description of 5 cases. Russian Psychiatric Journal. 2017; 2: 12-16.] (In Russ)

14. Голенков А.В., Орлов Ф.В., Булыгина И.Е., Деомидов Е.С. Постгомицидные самоубийства в России. Суицидология. 2019; 10 (2): 32-41. doi.org/10.32878/suiciderus. 19-10-02 (35)32-41. [Golenkov A.V., Orlov F.V., Bulygina I.E., Deomidov E.S. Post-homicide suicides in Russia. Suicidology. 2019; 10 (2): 32-41.] (In Russ)

15. Зотов П.Б., Спадерова Н.Н. Постгомицидные самоубийства в Тюменской области (Западная Сибирь) в 2008-2018 гг. Девиантология. 2019; 3 (2): 52-58. [Zotov P.B., Spaderova N.N. Posthomicide suicides in the Tyumen region (Western Siberia) in 2008-2018. Deviant Behavior (Russia). 2019; 3 (2): 52-58.] (In Russ)

16. Salari S. Patterns of intimate partner homicide suicide in later life: strategies for prevention. Clin. Interv. Aging. 2007; 2 (3): 441452.
17. Adhia A., DeCou C.R., Huppert T., Ayyagari R. Murder-Suicides Perpetrated by Adolescents: Findings from the National Violent Death Reporting System. Suicide Life Threat Behav. 2020. Apr; 50 (2): 534-544. DOI: 10.1111/sltb.12607.

18. Случаи нападения на сослуживцев в вооруженных силах РФ в 2001-2010 гг. https://ria.ru/20100611/245123366.html [Cases of attacks on colleagues in the armed forces of the Russian Federation in 2001-2010]. (In Russ)

19. Массовое убийство в Керченском политехническом колледже// wikipedia.org. [Электронный ресурс]. Режим доступа: https://ru.wikipedia.org/wiki/ (дата обращения: 12.05.2020). [Massacre at the Kerch Polytechnic College // wikipedia.org. [Electronic resource]. Access mode: https://ru.wikipedia.org/wiki/ (accessed: 05/12/2020).] (In Russ)

20. Национальное руководство по суицидологии / Под ред. Б.C. Положего. М.: МИА, 2019. 600 c. [National Guide to Suicidology / Ed. B.S. Polozhiy. Moscow: MИA, 2019. 600 p.] (In Russ)

21. Joiner $T$. The perversion of virtue: Understanding murder-suicide. New York, NY: Oxford University Press, 2014, 264 p.

22. Цымбалова А.Б., Ковалева Е.Ю., Голенкова В.А. Случаи убийств женщинами новорожденных детей (судебнопсихиатрический аспект). Актуальные вопросы психиатрии и наркологии: материалы республиканской науч.-практ. конф., посвященной 55-летию Республиканской психиатрической больницы. Чебоксары, 2017: 183-185. [Tsymbalova A.В., Коvaleva E.Yu., Golenkova V.A. Cases of murders by women of newborn children (forensic psychiatric aspect). Actual issues of psychiatry and narcology: materials of the Republican scientific and practical. Conf., dedicated to the $55^{\text {th }}$ anniversary of the Republican Psychiatric Hospital. Cheboksary, 2017: 183-185.] (In Russ)

23. Rougé-Maillart C., Jousset N., Gaudin A., Bouju B., Penneau M. Women who kill their children. Am.J. Forensic Med. Pathol. $2005 . \quad$ Dec; 26(4):320-326. DOI: 10.1097/01.paf.0000188085.11961.b2

24. Стрельба в школе № 263// wikipedia.org. [Электронный pecypc]. Режим доступа: https://ru.wikipedia.org/wiki/ Стрельба в школе № 263 (дата обращения 15.05.2020). [Shooting at school number $263 / /$ wikipedia.org. [Electronic resource]. Access mode: https://ru.wikipedia.org/wiki/ Shooting_in_shkole_№_263 (accessed 05.15.2020).] (In Russ)

25. Суходольская Ю.В. Криминологические аспекты и предупреждение массовых убийств в образовательных организациях. Законность. 2019; 6 (1016): 44-46. [Sukhodolskaya Yu.V. Criminological aspects and the prevention of mass killings in educational organizations. Legality. 2019; 6 (1016): 44-46.] (In Russ)

26. Kalesan B., Lagast K., Villarreal M., Pino E., Fagan J., Galea S. School shootings during 2013-2015 in the USA. Inj. Prev. 2017. Oct.; 23 (5): 321-327. DOI: 10.1136/injuryprev-2016-042162

27. Towers S., Gomez-Lievano A., Khan M., Mubayi A., CastilloChavez C. Contagion in Mass Killings and School Shootings. PLoS One. 2015. Jul. 2; 10 (7): e0117259. DOI: 10.1371/journal.pone.0117259. eCollection 2015.

28. Lankford A. Public Mass Shooters and Firearms: A CrossNational Study of 171 Countries. Violence Vict. 2016; 31 (2): 187-199. DOI: 10.1891/0886-6708.VV-D-15-00093

29. Lester D., Stack S., Schmidtke A., Schaller S., Müller I. The deadliness of mass murderers. Psychol. Rep. 2004. Jun; 94 (3 Pt 2): 1404. DOI: $10.2466 /$ pr0.94.3c.1404-1404

30. Lester D., Stack S., Schmidtke A., Schaller S., Müller I. Mass homicide and suicide deadliness and outcome. Crisis. 2005; 26 (4): 184-187. DOI: $10.1027 / 0227-5910.26 .4 .184$

31. Hanlon T.J., Barber C., Azrael D., Miller M. Type of Firearm Used in Suicides: Findings From 13 States in the National Violent Death Reporting System, 2005-2015. J. Adolesc. Health. 2019. Sep; 65 (3): 366-370. DOI: 10.1016/j.jadohealth.2019.03.015

32. Adhia A., Kernic M.A., Hemenway D., Vavilala M.S., Rivara F.P. Intimate Partner Homicide of Adolescents. JAMA Pediatr. 2019. Jun. 1; 173 (6): 571-577. DOI: 10.1001/jamapediatrics.2019.0621

33. Голенков А.В., Цымбалова А.Б. Результаты судебнопсихиатрической экспертизы подростков, совершивших 
убийства. Судебная психиатрия: современные проблемы теории и практики (диагностика, экспертиза, профилактика): материалы науч.-практ. конф. с международным участием. M., 2018: 43-45. [Golenkov A.V., Tsymbalova A.B. Results of a forensic psychiatric examination of adolescents who committed murders. Forensic psychiatry: current problems of theory and practice (diagnosis, examination, prevention): materials of scientific-practical. conf. with international participation. Moscow, 2018: 43-45.] (In Russ)

34. Карышев П.Б., Голенков А.В., Миронец Е.Н. Самоубийства среди детей и подростков Чувашии. XIV съезд психиатров
России: материалы съезда. М., 2005: 440-441. [Karyshev P.B., Golenkov A.V., Mironets E.N. Suicides among children and adolescents in Chuvashia. XIV congress of psychiatrists of Russia: materials of the congress. Moscow, 2005: 440-441]. (In Russ)

35. Chapman S., Alpers P., Agho K., Jones M. Australia's 1996 gun law reforms: faster falls in firearm deaths, firearm suicides, and a decade without mass shootings. Inj. Prev. 2006. Dec; 12 (6): 365 372. DOI: 10.1136/ip.2006.013714

36. Patton C.L., McNally M.R., Fremouw W.J. Military Versus Civilian Murder-Suicide. J. Interpers Violence. 2017. Sep; 32 (17): 2566-2590. DOI: 10.1177/0886260515593299

\section{ADOLESCENT POST-HOMICIDE SUICIDES}

\section{A.V. Golenkov}

I.N. Ulyanov Chuvash State University, Cheboksary, Russia; golenkovav@inbox.ru

\section{Abstract:}

Adolescent post-homicide suicides (PHSU) are extremely rare. However, in the last two decades their number has significantly increased. The purpose of the research was to study adolescent PHSU in the Russian Federation. Materials and methods. The analysis included 12 adolescents who completed PHSU, aged 16 to 19 (mean age 18.2 \pm 1.1 ). Information about the crimes was collected in the electronic media, on the websites of the Investigative Committee of 11 constituent entities of the Russian Federation during the period from January 1, 2009 to December 31, 2019. Data on 39 victims of PHSU (23 males and 16 females) aged 4 to 69 (mean age $-27.3 \pm 17.5$ ) was also analyzed, as well as their socio-demographic, psychopathological and criminological indicators. Results. Boys completed 11 PHSU, girls - one (seven happened in urban areas and five occurred in rural areas). Most often ( $\mathrm{n}=8$ ), extrafamily PHSU occurred, then intimate (partner) $(n=3)$ and family $(n=1)$ followed. In $50.0 \%$ of cases, firearms were used, in 33.4\% - steel arms, and others (asphyxiation, several methods) - in 16.6\%. The methods of homicide and suicide were identical in $75.0 \%$ of cases; in $83.3 \%$ cases suicides occurred in the same place as the murder shortly after it. $43.6 \%$ of the victims were aged 13-19 and the same number was aged 20-64. 30 people died in three PHSU (mass shooting of students and staff at a college in Kerch; shooting of an officer and soldiers in a military base located in the Kostroma region and killing with an ax of the members of three generations of a family in the Ulyanovsk region). The reasons for PHSU were: prolonged conflicts (bullying, hazing in the army), parting with a partner (girlfriend), fear of criminal punishment for murder, not to make relatives worry after the suicide. Mental disorders were confirmed in one case, as was alcohol intoxication (from psychoactive substances) at the time of PHSU. Suicidal tendencies before the homicide were detected in $33.3 \% ; 75.0 \%$ of the homicides can be classified as committed intentionally. Adolescent PHSU have a particularly high proportion of peer victims; killing of young children is quite rare; extra-family PHSU prevail, aggressors, as a rule, are younger than victims. Conclusion. Due to its rarity, adolescent PHSU have not been properly studied, prevention is practically not developed and in many aspects is the same as the measures to prevent homicides and suicides among young people. The number of victims of PHSU can be reduced by restricting adolescents' access to firearms and controlling their use.

Keywords: post-homicide suicides, adolescents (teenagers), mass murders, Russia, online media reports

Вкмад автора:

А.В. Голенков: разработка дизайна исследования; написание текста рукописи; редактирование текста рукописи. Authors' contributions:

A.V. Golenkov: developing the research design, article writing and editing.

Финансирование: Данное исследование не имело финансовой поддержки.

Financing: The study was performed without external funding.

Конфмикт интересов: Автор заявцяет об отсутствии конфцикта интересов.

Conflict of interest: The author declares no conflict of interest.

Статья поступима / Article received: 18.05.2020. Принята к публикации / Accepted for publication: 01.07.2020.

Для цитирования: Голенков А.В. Подростковые постгомицидные самоубийства. Суицидология. $2020 ; 11$ (2): 3-14. doi.org/10.32878/suiciderus.20-11-02(39)-3-14

For citation: $\quad$ Golenkov A.V. Adolescent post-homicide suicides. Suicidology. 2020; 11 (2): 3-14. (In Russ) doi.org/10.32878/suiciderus.20-11-02(39)-3-14 